\title{
Librarians Partner Across Campus to Support Undergraduate Research
}

\begin{abstract}
University librarians serve a critical role in educating undergraduate students about information literacy, which is extensively documented in the research literature. However, faculty librarians, especially those affiliated with large research-intensive universities, also possess highly specialized training and knowledge that position them as highly effective mentors to undergraduates. Yet there is scant research documenting the contributions of faculty librarians who serve as mentors to undergraduate researchers (Harwood and McCormack 2008). This article describes an innovative program model, the Undergraduate Research Experiences Library Program (URELP), which was developed by the directors of the Office for Undergraduate Research in partnership with academic librarians at the University of South Florida. Now in its third year, the program creates additional opportunities for students in all disciplines and at all levels seeking interdisciplinary undergraduate research experiences. Another program, Creating Research Experiences and Activities Through Teaching Enhancement (CREATTE), has increased UR capacity in the context of structured courses that also frequently rely on faculty librarians.
\end{abstract}

The extensive literature on undergraduate research investigates the practice from a variety of perspectives including student gains, capacity issues, faculty engagement, and summer research experiences (Bauer and Bennett 2003; Frost and Teodorescu 2001; Karukstis and Elgren 2007; Kuh 2008; Thiry, Laursen, and Hunter 2011; Urias, Gallagher, and Wartman 2012). However, little attention has been focused on how faculty librarians mentor undergraduates. Two recent studies do provide models for librarians as research mentors (Harwood and McCormack 2008; Hayes-Bohanan 2013), although both involve projects that center on information literacy, and one project was specifically designed for students interested in library careers (Harwood and McCormack). While these projects represent excellent opportunities for student engagement with research, this article fills a gap in the literature by focusing on the contributions of librarians as both information-literacy educators and research mentors, thus illustrating librarians' work beyond their "traditional" roles.

Faculty librarians, especially those affiliated with large research-intensive universities, possess specialized training and knowledge that position them to be highly effective mentors to undergraduates. While an abundance of literature focuses on the role of librarians as purveyors of information literacy (Ross and Sennyey 2008; Smith and Daily 2013), there are few examples in the literature that document the contributions of faculty librarians who serve as mentors of undergraduate researchers (Harwood and McCormack 2008). In addition, the bulk of literature on the practice of undergraduate research (UR) centers on the science, technology, engineering, and mathematics (STEM) disciplines, with limited published research focusing on undergraduate research experiences in the humanities and the arts (Klos, Shanahan, Olin, and Young 2011).

The two programs described in this article, the Undergraduate Research Experiences Library Program (URELP) and the Creating Research Experiences and Activities Through Teaching Enhancement (CREATTE) program illustrate UR in non-STEM disciplines. Each program, in distinct ways, aims to expand undergraduate research capacity at our research-intensive university, and both programs use the institution's rich and varied library resources, the research expertise of faculty librarians, and the resources of the Office for Undergraduate Research (OUR) to expand students' opportunities for research.

Established in 2012, the URELP program was developed by OUR in partnership with USF academic librarians. Students who participate in URELP projects work closely with librarians to develop projects based on their interests and to identify library collections of interest. The CREATTE program, also established in 2012, aims to increase UR capacity within the context of a structured course. Students who participate in CREATTE courses work closely with faculty mentors to develop projects. Several CREATTE projects have been developed around the library's archival collections, with librarians serving as consultants and/or co-mentors on these projects.

Designated as a very high research activity institution by the Carnegie Foundation, USF is one of the largest universities in the nation with a total system enrollment of more than 48,000 (USF Pocket Facts 2014-15). Student success, research, and preparing students for a globally competitive environment are at the center of the university's mission and vision, which also strongly emphasize high-impact educa- 
tional practices (Kuh 2008) such as undergraduate research. A major challenge in an institution of this size is the ratio between students seeking to do research and the availability of faculty and graduate student mentors. Thus, a primary feature of the OUR's mission involves the development of collaborative initiatives to increase UR capacity on campus across all disciplines.

OUR was relocated to the USF Tampa Library in 2011 and became part of the library's Learning Commons, which includes several academic support services such as the SMART Lab, Academic Success Center, and Writing Studio. The central location of OUR within the USF Library has facilitated numerous collaborations among OUR, library units, and faculty librarians. Author Smith, for example, serves as the librarian liaison to OUR, providing library support to both OUR staff and undergraduate researchers. OUR itself is a small unit but serves a population of more than 30,000 undergraduates.

With a collection of more than one million books, 52,000 e-journals, 400,000 e-books, 800 databases, and a voluminous Special Collections unit, the USF Tampa Library offers numerous possibilities for undergraduate research. URELP involves comprehensive instruction in the research process, hands-on experience with research objects such as archival materials and oral histories, and an emphasis on tangible student outcomes including students' presentation of research findings at the annual USF OUR Research and Arts Colloquium. Since 2012, USF faculty librarians have mentored close to 20 undergraduates majoring in a variety of disciplines. URELP students' projects have explored a diversity of topics including genocide in the African and Armenian contexts, local Tampa history, and genealogical research.

\section{The URELP Program}

The details of URELP, specifically the process and aims of the program, emerged from a close collaboration between OUR and the library and a shared vision for supporting students' success. Over the course of several months, OUR directors and research librarians met to discuss the design of the program, including program outcomes and assessment, and strategies for carefully aligning the program with the strategic goals of the units and those of the institution. For instance, early discussions focused on the URELP application process. OUR directors and faculty librarians decided that the application process should be designed to encourage students to take an active role in the process. Thus, for example, URELP applicants must research and identify a specific collection of interest and propose a relevant research question as part of the application process. This introduces student inquiry and discovery into the application process.

Since program outcomes were also a central consideration in the program's design, URELP projects have specific learning goals that include developing search skills in choosing and using appropriate online databases, being able to analyze print and digital documents, evaluating and combining evidence from primary source material in order to create valid research conclusions, and sharing research results with an academic audience through documentation and presentation. Students who participate in URELP projects learn the foundations of the research process, gain hands-on experience with research objects such as archival materials and oral histories, and gain valuable experience through the presentation of research findings at the annual spring research colloquium. This experience also serves to showcase the interdisciplinary research that utilizes the rich repository of the library's Special Collections. To date, 14 students have presented URELP projects at the colloquium, and three URELP students have been awarded Excellence in Undergraduate Research Awards since 2013. A summary of URELP student and librarian participation and outcomes is presented in Table 1.

Table 1. URELP Participation and Outcomes, 2013-2015

\begin{tabular}{|l|l|l|l|l|}
\hline YEAR & $\begin{array}{l}\text { Librarian } \\
\text { Mentors }\end{array}$ & $\begin{array}{l}\text { Students } \\
\text { Mentored }\end{array}$ & $\begin{array}{l}\text { Colloquium } \\
\text { Student } \\
\text { Presenters }\end{array}$ & $\begin{array}{l}\text { Research } \\
\text { Excellence } \\
\text { Awards }\end{array}$ \\
\hline 2013 & 4 & 4 & 4 & 1 \\
\hline 2014 & 4 & 7 & 7 & 1 \\
\hline 2015 & 2 & 3 & 3 & 1 \\
\hline Total & 10 & 14 & 14 & 3 \\
\hline
\end{tabular}

As indicated above, URELP also was designed around key strategic goals of OUR, the USF Library, and the larger strategic goals of the institution. For example, the URELP program targets a strategic goal of the USF library: Sustain and expand a library instruction program in collaboration with faculty which is continuously assessed for its effectiveness and impact on student academic success. The program also aligns with OUR's strategic goal: Collaborate with university partners to develop creative initiatives that promote undergraduate research.

OUR directors and faculty librarians created a survey instrument to capture student perceptions about their URELP experiences, which students complete at the beginning and end of the URELP experience. Qualitative excerpts of the comments of student respondents include:

Many people are under the impression that research projects are directed mainly to Scientific and Medical 
concentrations. I feel very lucky to have seen this project when I did and participated. This will also help in my future efforts to get projects in the editing field. (an English major)

I think research projects, like this one, that focus on a historical perspective are very important. With so many changes in health care and health care policy, it is important to understand that while the health system is not perfect, it has made significant steps forward. (a biomedical science major)

The main reason that I chose to participate in the research project was my interest in the material. Therefore, having a deeper understanding of that material was the major goal of my research. (mass communication major)

In addition, several URELP mentors are also collecting student case studies to document and assess programming and the experiences of URELP students. For example, in the spring of 2014, a USF Tampa librarian with experience in genealogical research sought undergraduates' help for a research project to locate the living relatives of boys who had died at the Arthur G. Dozier School for Boys, a state-operated reform school located in the Florida Panhandle that had closed in 2011 after operating for more than 100 years. The intent was to compare the DNA of living relatives with DNA extracted from remains buried at the school in an attempt to identify the remains for family members. The librarian crafted an ad for the OUR website, reviewed the resulting applications, and selected three of the applicants for the project. Of those three, two chose to join the research project and stayed with it for more than a year.

During the research project, the librarian mentored the two students, training them in genealogical research techniques using available online databases. The students were given access to digitized documents unique to the Dozier School and to the deceased boys. The students met regularly with their mentor, sharing their progress and working together to decide upon research strategies. As a result of their research, several additional sets of living relatives were identified, and in at least one case, a successful DNA match was made between a set of remains and a family of living relatives. The students submitted their research project to the OUR spring colloquium, and were selected to present. The librarian gave the students feedback on their presentation ahead of time and scheduled a practice presentation attended by other librarians. As a result of feedback from all the librarians, the students felt better prepared for the actual event.

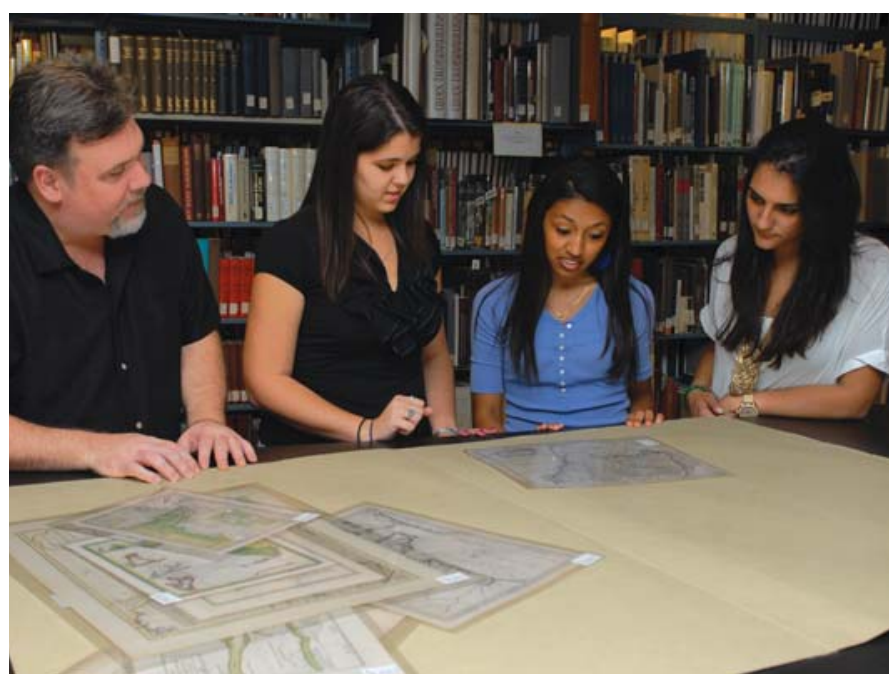

Students learn about the USF Special Collections from faculty librarian Andy Huse.

\section{The CREATTE Program}

Like URELP, the CREATTE initiative was designed around targeted program outcomes and assessment and in alignment with the strategic goals of OUR and the institution. The program is restricted to non-laboratory courses, and it was specifically designed to support UR experiences within structured courses in the social sciences, humanities, and the arts. The program encourages faculty scholars to design and implement creative pedagogy and utilize innovative strategies to actively engage students in the research process. One such strategy that has been encouraged by OUR and employed by several CREATTE scholars is the design of courses around the library's archival collections. Several of these courses have been designed with the assistance of faculty librarians and with librarians serving as consultants and co-mentors on student projects.

For example, in the fall 2013 semester, the general education course LIT3301, Cultural Studies \& the Popular Arts: Dime Novels at USF was re-imagined as a digital humanities course. Students in the course received comprehensive instruction in humanities research and the development of an online exhibition. Course objectives included developing a research question, identifying and evaluating resources, and composing research briefs to record research progress. 
Weekly classes were held in the library with easy access to the Special Collections. Student outcomes for the course included digitizing two dime novels from the USF collection, preparing a plot summary of each novel, and providing contextual analysis using primary and secondary sources. With the assistance of Special Collections librarians, students also created several online exhibitions using Omeka, an open-source platform. Several groups of students in the course presented their research projects at the 2013 spring research colloquium, and one group received an award for the excellence of their poster. This example demonstrates a high level of collaboration between faculty, librarians, and OUR. Students in the course received research training and instruction and support from a variety of mentors including faculty, librarians, and graduate student assistants, resulting in a highly supportive research experience.

To assess CREATTE program outcomes, OUR staff designed a Likert-type survey, which more than 60 students now have completed at the conclusion of the course. The survey collects student evaluations of the project and of the research mentors, and reports students' confidence in mastery of 16 research competencies. A primary feature of all CREATTE courses is presentations at the spring research colloquium. Through 2012, 212 CREATTE participants presented their research, including 33 students who were enrolled in libraryfocused CREATTE courses (Table 2).
Table 2. CREATTE Student Colloquium Participation, 2012-2015

\begin{tabular}{|l|l|l|l|l|l|}
\hline & 2012 & 2013 & 2014 & 2015 & Total \\
\hline $\begin{array}{l}\text { Total Colloquium } \\
\text { Presenters }\end{array}$ & 176 & 290 & 296 & 387 & 1142 \\
\hline CREATTE Presenters & $0 *$ & 88 & 45 & 79 & 212 \\
\hline $\begin{array}{l}\text { Library-focused CREATTE } \\
\text { Presenters }\end{array}$ & $0 *$ & 13 & 12 & 8 & 33 \\
\hline
\end{tabular}

${ }^{*}$ CREATTE established fall 2012

Preliminary CREATTE assessment data has revealed encouraging trends in students' reported learning gains in library-focused CREATTE courses. For instance, in response to a question about proficiency in use of library resources, 86 percent of students who participated in a library-focused CREATTE course indicated that they had developed much or extensive experience with this competency, and 90 percent noted much or extensive experience in ability to locate resources to solve a problem. In addition, 89 percent of students indicated that they developed much or extensive experience with making connections among the research problem, subject area, and the stimulation of new ideas. The distribution of responses is presented in Table 3.

Table 3. Student Reports of Gains in Library-Proficiency Measures

\begin{tabular}{|c|c|c|c|c|c|c|c|c|c|c|}
\hline \multirow[t]{2}{*}{$\begin{array}{l}\text { After taking the CREATTE course } \\
\text { please rate your competency to } \\
\text { the measure below }\end{array}$} & \multicolumn{2}{|c|}{$\begin{array}{l}\text { No experience or } \\
\text { not confident in } \\
\text { proficiency }\end{array}$} & \multicolumn{2}{|c|}{ Little experience } & \multicolumn{2}{|c|}{ Some experience } & \multicolumn{2}{|c|}{$\begin{array}{l}\text { Much } \\
\text { experience but } \\
\text { not mastery }\end{array}$} & \multicolumn{2}{|c|}{$\begin{array}{l}\text { Extensive } \\
\text { experience and } \\
\text { ability to show } \\
\text { mastery }\end{array}$} \\
\hline & Total & $\begin{array}{l}\text { Percent } \\
\text { of total }\end{array}$ & Total & $\begin{array}{l}\text { Percent } \\
\text { of total }\end{array}$ & Total & $\begin{array}{l}\text { Percent } \\
\text { of total }\end{array}$ & Total & $\begin{array}{l}\text { Percent } \\
\text { of total }\end{array}$ & Total & $\begin{array}{l}\text { Percent } \\
\text { of total }\end{array}$ \\
\hline Ability to use USF library resources & 0 & 0 & 0 & 0 & 9 & 14 & 17 & 27 & 37 & 59 \\
\hline $\begin{array}{l}\text { Ability to navigate/locate } \\
\text { resources to solve a problem }\end{array}$ & 0 & 0 & 0 & 0 & 6 & 10 & 10 & 16 & 47 & 74 \\
\hline $\begin{array}{l}\text { Understanding of how the solution } \\
\text { to the problem contributes to the } \\
\text { subject area and stimulates new } \\
\text { ideas }\end{array}$ & 0 & 0 & 0 & 0 & 7 & 11 & 23 & 37 & 33 & 52 \\
\hline
\end{tabular}

$N=63$ total responses to each measure 


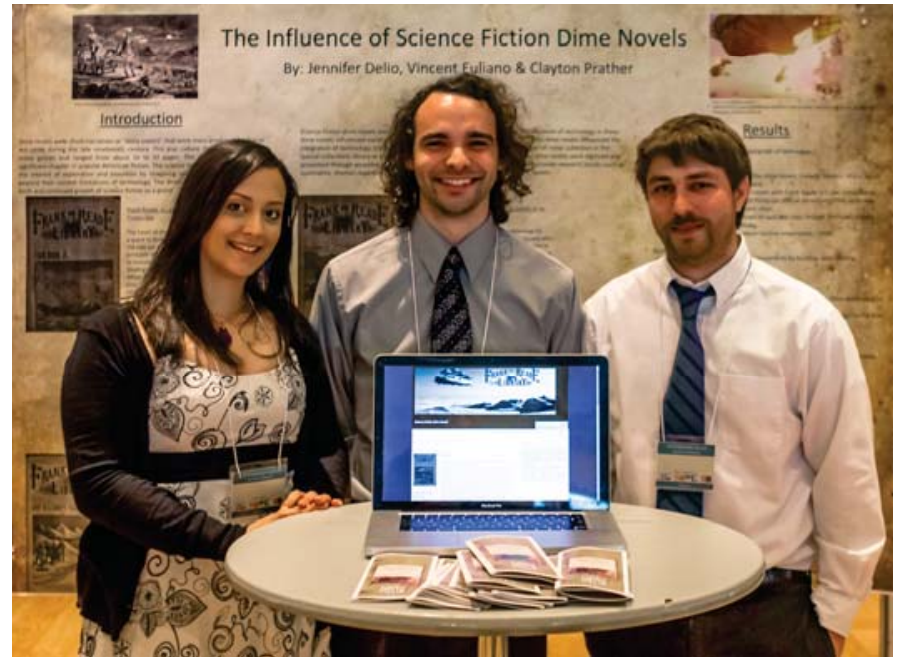

Student researchers Jennifer Delio (public health), Vincent Euliano (music composition), and Clayton Prather (music) present a poster during the 2013 OUR Research and Arts Colloquium.

\section{Final Thoughts and Implications for Practice}

The URELP and CREATTE programs aim to expand undergraduate research capacity at a research-intensive university through the institution's rich library resources, the research expertise of faculty librarians, and the resources of the Office for Undergraduate Research. The collaborative partnerships among the units have led to new ways of conceptualizing the possibilities for undergraduate research, centered on the expertise of library faculty as both information-literacy educators and research mentors. The impact and potential outcomes of librarian-mentored undergraduate research are captured in students' reflections. Excerpts from the URELP student survey include:

My mentor helped me to access a larger number of resources and was excellent to talk with as I focused my gathering thoughts. She gave me the freedom to work without too much oversight, but we both knew that I would ask for assistance as needed. (interdisciplinary social science major)

This course required a greater depth of research than any previously taken courses. The manner of this research showed me how to be more methodical with research. It was beneficial. (third-year business major)

Although the URELP and CREATTE programs continue to expand, growth is strategic to ensure that the quality of the experience for both students and research mentors continues to improve. We believe that both the URELP and CREATTE models are easily adaptable to a variety of institutional types. For instance, smaller colleges with archival collections can adapt many, if not all, of the features of the URELP and CREATTE models described here. Research-intensive universities with similar library units and research offices can easily adapt the URELP and CREATTE models to serve the unique needs of the student population and to increase student capacity in undergraduate research. Finally, collaborative partnerships such as the two models described here add value to a student's educational experience and enrich the entire university community. The important scholarship that these student researchers have contributed to the body of knowledge is the epitome of the undergraduate research experience.

\section{References}

Bauer, Karen W. and Joan. S. Bennett. 2003. "Alumni Perceptions Used to Assess Undergraduate Research Experience." The Journal of Higher Education 74 (2): 210-230. doi: 10.1353/jhe.2003.0011.

The Carnegie Classification of Institutions of Higher Education. University of South Florida. Retrieved from http://carnegieclassifications.iu.edu/.

Frost, Susan H. and Daniel Teodorescu. 2001. "Teaching Excellence: How Faculty Guided Change at a Research University." The Review of Higher Education 24 (4): 397-415. doi: 10.1353/rhe.2001.0007.

Harwood, Doreen and Charlene McCormack. 2008. "Growing Our Own: Mentoring Undergraduate Students." Journal of Business \& Finance Librarianship 13 (3): 201-215. doi: 10.1080/08963560802183195.

Hayes-Bohanan, Pamela. 2013. "Librarian Mentoring of Undergraduate Research." Journal of Library Innovation 4 (1): 21-28.

Karukstis, Kerry. K. and Timothy E. Elgren. 2007. Developing and Sustaining a Research-supportive Curriculum: A Compendium of Successful Practices. Washington, DC: Council on Undergraduate Research.

Klos, Naomi, Yavneh Shanahan, Jenny Olin, and Gregory Young. 2011. Creative Inquiry in the Arts \& Humanities: Models of Undergraduate Research. Washington, DC: Council on Undergraduate Research.

Kuh, George. 2008. High-Impact Educational Practices: What They Are, Who Has Access to Them, and Why They Matter. Washington, D.C.: Association of American Colleges and Universities.

Ross, Lyman and Pongracz Sennyey. 2008. "The Library is Dead, Long Live the Library! The Practice of Academic Librarianship and the Digital Revolution." Journal of Academic Librarianship 34 (2): 145-152. doi: 10.1016/j. acalib.2007.12.006.

Smith, Meggan D. and Amy B. Daily. 2013. "Improving and Assessing Information Literacy Skills through Faculty-Librarian Collaboration. College \& Undergraduate Libraries 20 (3/4): 314-326. doi: 10.1080/10691316.2013.829370. 
Thiry, Heather, Sandra L. Laursen and Anne-Barrie Hunter. 2011. "What Experiences Help Students become Scientists? A Comparative Study of Research and Other Sources of Personal and Professional Gains for STEM Undergraduates." Journal of Higher Education 82 (4): 357-388. doi: 10.1353/ jhe.2011.0023.

University of South Florida. About USF: Mission and Vision. Retrieved from http://www.usf.edu/about-usf/mission-vision.aspx.

Univeristy of South Florida. USF System Facts 2014-2015. Retrieved from http://usfweb.usf.edu/dss/Infocenter/Surveys/pocket-facts/USF-POCKETFACTS-2014-15.pdf.

Urias, David, Patricia Gallagher and Joseph Wartman. 2012. "Critical Features and Value in Assessing a Research Experience for Undergraduates: The Case of Engineering Cities." Journal of STEM Education 13 (1): 30-42.

\section{Lisa M. Piazza}

University of South Florida, Impiazza@usf.edu

Lisa M. Piazza, assistant director of the Office for Undergraduate Research (OUR) at the University of South Florida, focuses on program development and student instruction. Her research focuses on undergraduate research programming and assessment, undergraduate research in the arts, and international issues in undergraduate research. She holds a $B A$ in art history from the University of South Florida and an MA in art history from the University of North Carolina at Chapel Hill. She is a doctoral candidate in the USF College of Education.

Richard S. Pollenz is professor of cell biology, associate dean of undergraduate studies, and director of the Office for Undergraduate Research at the University of South Florida. Pollenz investigates innovations in teaching and learning that engage undergraduates in research to enhance their academic progression and professional development. He was named an AAAS Fellow for his work in molecular toxicology and also has received several teaching awards and grant funding to support innovations in undergraduate education, such as the use of karaoke and music as a teaching tool in the biological sciences. He is currently directing the university's STEM Academy program, funded by the Howard Hughes Medical Institute.

Drew Smith is an assistant librarian in the academic services unit of the University of South Florida Tampa Library. He is liaison librarian to several academic departments, including the Office for Undergraduate Research. Smith holds a BS in electrical engineering and an MS in industrial management from Clemson University, and an MA in library and information science from USF. His research focuses on college-level teaching and learning, copyright, and genealogical research.

\section{doi: $10.18833 /$ curq/36/4/1}

